\title{
The Probiotic BioPlus 2B as an Alternative to Antibiotics in Diets for Broiler Chickens
}

\author{
J. ŠABATKOVÁ ${ }^{1}$, I. KUMPRECHT ${ }^{2}$, P. ZOBAČ ${ }^{2}$, P. SUCHÝ ${ }^{3}$, B. ČERMÁK ${ }^{4}$ \\ ${ }^{1}$ Lucta, Prague, Czech Republic \\ ${ }^{2}$ Research Institute for Animal Nutrition, Pohořelice, Czech Republic \\ ${ }^{3}$ Department of Nutrition, Animal Husbandry and Animal Hygiene, Faculty of Veterinary Hygiene and Ecology, \\ University of Veterinary and Pharmaceutical Sciences Brno, Czech Republic \\ ${ }^{4}$ Department of Animal Genetics, Breeding and Nutrition, Faculty of Agriculture, University of South Bohemia, \\ Czech Republic
}

Received March 10, 2008

Accepted June 11, 2008

\begin{abstract}
Šabatková J., I. Kumprecht, P. Zobač, P. Suchý, B. Čermák: The Probiotic BioPlus 2B as an Alternative to Antibiotics in Diets for Broiler Chickens. Acta Vet. Brno 2008, 77: 569-574.

The main aim of this work was to compare the stimulatory effect of the probiotic BioPlus $2 \mathrm{~B}$ with that of the antibiotic Avilamycin on the growth and feed conversion in broiler chickens. The growth experiment was performed with one-day-old sexed female and male ROSS 308 hybrid chickens (240 females and 240 males) placed in 24 cages. They were fed the starter diet from Day 1 to Day 14, followed by the grower from Day 15 to Day 35 and the finisher in a loose form from Day 36 to Day 42. Diets and water were available ad libitum. The control slaughter of chickens was performed at the end of the experiment (Day 42) to determine the slaughter yield and the content of inner fat in the final product. The supplementation of the diets used in broiler prefattening and fattening with BioPlus $2 \mathrm{~B}$ resulted in a $4-5 \%$ weight gain $(P<0.01)$ and in a $4-5 \%$ improvement $(P<0.01)$ in feed conversion. Mean slaughter yields were higher $(P<0.01)$ in chickens fed diets containing probiotic and antibiotic products compared to the group of chickens fed the diet not supplemented with a growth promotor. The weight of inner fat in chickens under study did not differ significantly either between experimental groups or between sexes.
\end{abstract}

\section{Growth experiment, feed conversion, performance, slaughter yield, Avilamycin, biological growth} promotor, probiotics

The fundamental principle of in-feed antibiotics and probiotics is that they influence the composition of intestinal microflora in favour of the host. Scientific studies have shown a beneficial effect of such products on the growth, feed consumption, and stabilization of animal health.

However, a long-term use of antibiotics and chemical growth promotors increases the occurrence of resistant pathogenic micro-organisms and reduces the efficacy of antibiotics and chemotherapeutics in the treatment of some diseases. Concerns about a further decrease in the efficacy of therapeutic antibiotics led to the ban on the use of antibiotics and chemical growth promotors in animal nutrition. However, besides strict adherence to hygiene requirements and proper nutrition, suitable biological products stabilizing the health of animals in agricultural farms which would have a beneficial effect not only on growth and nutrient conversion but also on the environment, are keenly sought for.

One of the ways of achieving the above-mentioned effects is to use additives which support the practical applications and development of probiotics and which include organic acids, bioplexes, manno-oligosaccharides (Kumprecht and Zobač 2000). Traditional probiotics include the products containing live stabilized cultures of exactly defined microorganisms as active components.

Microflora in the chicken's digestive tract is affected by feed composition and particularly 
by age. The normal colonization of chicken's caecum with bacteria is established within 4-6 weeks (Mead 1989). One-day-old chickens are ideal subjects to administer probiotics to, since they are hatched practically sterile and have no contact with parents.

Ghadban (2002) provides an overview of studies on the use of probiotics in poultry nutrition. Probiotics are biological products stimulating the immune system and increasing its defensive activity against pathogenic bacteria.

The experiments with chicken diets containing probiotics based on Bacillus sp. that were conducted by Kumprecht and Zobač (1998) indicate that the use of suitable biological products in broiler fattening may lead to a decreased excretion of nitrogen in excrements, thereby helping to reduce environmental pollution.

Patterson and Burkholder (2003) showed the suppression of pathogenic microorganisms in the gastrointestinal tract with the use of a probiotic product containing Lactobacillus cultures as an additive to diets for broiler chickens.

Research into the effects of two commercial probiotics applied in drinking water, feed or spray on the production performance and the quality of the final product in broiler chickens was studied by O'Dea et al. (2006), showing that the probiotics used had a beneficial effect on chickens' health rather than a conclusive effect on the monitored indicators.

In order to improve the performance and stabilize microflora in the digestive tract of broilers, Fritts et al. (2000) used the probiotic product containing Bacillus subtilis C-3102 (Calsporin). When this product was administered to chickens in the diet for a period of 42 days, their live weight increased and feed conversion improved.

The main aim of this study was to compare the efficacy of BioPlus 2B with that of the antibiotic Avilamycin on performance indicators and slaughter yields in broiler chickens. The probiotic BioPlus 2B contains Bacillus licheniformis - CH 200 and Bacillus subtilis $\mathrm{CH} 201$. Both bacterial species are characterized by a high production of proteases, lipases, and amylases in the small intestine. They also accelerate the metabolism and increase nutrient utilization. At the same time, they produce volatile fatty acids that decrease the $\mathrm{pH}$ of the digestive tract, enhance the development of lactacidogenic microflora, and reduce the number of pathogenic E. coli. The European Commission dealing with additives, products and substances used in animal nutrition approved BioPlus $2 \mathrm{~B}$ as a feed additive in compliance with Council Directive No. 70/524/EEC (EFSA 2003).

\section{Materials and Methods}

The growth experiment included one-day-old sexed female and male ROSS 308 hybrid chickens. Oneday-old chickens were placed in cages in the experimental enclosure of the Jinačovice farm belonging to the University of Veterinary and Pharmaceutical Sciences, Brno. One cage sized $92 \mathrm{~cm} \times 190 \mathrm{~cm} \times 44 \mathrm{~cm}(\mathrm{~W} \times \mathrm{L} \times$ $\mathrm{H})$ accommodated 20 chickens of the same sex. A total of 240 females and 240 males were placed in 24 cages. The chickens were given the starter mixture from Day 1 to Day 14, followed by the grower from Day 15 to Day 35 and the finisher in a loose form from Day 36 to Day 42. The composition of the diets and the content of nutrients are specified in Table 1.

The experiment was designed as a two-factor experiment with replicates, according to the formulae A (3) $\times \mathrm{B}$ $(2) \times(80)$ for growth and A (3) $\times$ B (2) $\times(4)$ for feed consumption per $\mathrm{kg}$ of a weight gain where

f A stands for biologicals

$\mathrm{a}_{0}$ - Control diets without growth promoters

$\mathrm{a}_{1}$ - Diets containing Avilamycin

$\mathrm{a}_{2}$ - Diets containing BioPlus 2B

$\mathrm{f} B$ stands for sex

$\mathrm{b}_{0}$ - Female chickens

$\mathrm{b}_{1}$ - Male chickens

Biofactor supplements were produced by Biofaktory Praha s.r.o.

Avilamycin was added to all diets $\left(a_{1}\right)$ at the dosage of $10 \mathrm{~g} \cdot \mathrm{t}^{-1}$

The probiotic product BioPlus 2B (supplied by Biochem Praha spol. s r.o.) contains Bacillus licheniformis - $\mathrm{CH}$ 200 and Bacillus subtilis - CH 201 at a ratio of $1: 1$; the basic product contains $3.2 \times 10^{9}$ of sporulating bacteria 
Table 1. Composition of diets administered to broiler chickens

\begin{tabular}{|l|c|c|c|}
\hline \multirow{2}{*}{ Components } & \multicolumn{3}{|c|}{ Labelling of feeding mixtures } \\
\cline { 2 - 4 } & \multicolumn{3}{|c|}{ Content in \% } \\
\hline & starter & grower & finisher \\
\hline Maize & 36.6 & 30.0 & 45.0 \\
\hline Wheat & 30.0 & 38.6 & 30.0 \\
\hline Soy-extracted meal & 20.2 & 16.4 & 12.1 \\
\hline Vitex Q yeast & - & 2.0 & 2.0 \\
\hline Meat and bone meal & 3.0 & 7.0 & 7.0 \\
\hline Fish meal & 6.0 & 3.0 & 1.0 \\
\hline Sunflower oil & 2.0 & 2.0 & 1.7 \\
\hline Threonine px 20 & 0.1 & - & - \\
\hline Lysine px 60 & 0.3 & 0.3 & 0.4 \\
\hline Methionine px 50 & - & 0.1 & 0.1 \\
\hline Monocalcium phosphate & 0.5 & - & - \\
\hline Lime & 0.7 & - & - \\
\hline Salt & 0.1 & 0.1 & 0.2 \\
\hline Aminovitan BR1 & 0.5 & - & - \\
\hline Aminovitan BR2 & - & 0.5 & - \\
\hline Aminovitan BR3 & - & - & 0.5 \\
\hline Total & 100 & 100 & 100 \\
\hline Dry matter & 89.03 & 89.24 & 89.12 \\
\hline Crude protein & 22.00 & 21.68 & 19.05 \\
\hline Fat & 5.08 & 5.35 & 5.30 \\
\hline Fibre & 2.98 & 2.92 & 2.79 \\
\hline Ash & 5.73 & 5.17 & 4.71 \\
\hline Nitrogen-free extract & 53.06 & 53.99 & 57.27 \\
\hline Lysine & 1.26 & 1.19 & 1.03 \\
\hline Methionine & 0.60 & 0.57 & 0.49 \\
\hline Methionine + cystine & 0.94 & 0.91 & 0.79 \\
\hline Calcium & 1.01 & 0.91 & 0.70 \\
\hline Phosphorus, total & 0.79 & 0.71 & 0.69 \\
\hline Phosphorus, digestible & 0.49 & 0.43 \\
\hline MEd MJ / kg & 12.62 & 12.78 & 13.00 \\
\hline
\end{tabular}

per gram and lactose used as a carrier. BioPlus 2B was added to diets $\left(\mathrm{a}_{2}\right)$ at the following doses: $1000 \mathrm{~g} \cdot \mathrm{t}^{-1}$ to BR1, $400 \mathrm{~g} \cdot \mathrm{t}^{-1}$ to BR2 and BR3.

Chickens received the diets and water ad libitum. Air temperature and humidity were adjusted according to the ROSS technological procedure for broiler fattening. Illumination was constant. The chickens were weighed on Days 1, 14, 35, and 42, at an accuracy of $\pm 1 \mathrm{~g}$. The consumption of diets was monitored continually for each cage at the following intervals of consumption monitoring: Days 1-14, Days 15-35, and Days 36-42. At the end of the experiment (Day 42), 42-day-old chickens were subjected to control slaughter to determine the slaughter yield and the content of inner fat in the final product.

The results were evaluated using a two-factor analysis of variance. The significance of differences between the mean values of monitored experimental variables was evaluated using Scheffe's test (Snedecor and Cochran 1967).

\section{Results and Discussion}

The mean weight of broiler chickens in the monitored growth phases are listed in Table 2 . The weight of chickens aged 14 days (Day 14) increased $(P<0.01)$ with the use of both the antibiotic Avilamycin $\left(\mathrm{a}_{1}\right)$, and the probiotic BioPlus 2B $\left(a_{2}\right)$. The weight of chickens in Group $\left(a_{2}\right)$ and Group $\left(a_{1}\right)$ in this period increased by $8.14 \%$ and $4.89 \%$, respectively, compared to the control group $\left(a_{0}\right)$. No significant difference was found between Groups $\left(a_{1}\right)$ and $\left(a_{2}\right)$ No difference was found between 14-day-old male and female chickens.

The mean weight of chickens in Groups $\left(\mathrm{a}_{2}\right)$ and $\left(\mathrm{a}_{1}\right)$ on Day 35 was $3.89 \%(P<0.01)$ and $2.18 \%(P<0.05)$ higher, respectively, compared to the control group. The weight of male chickens increased (by $6.96 \%, P<0.01$ ) in this period of monitoring compared to female chickens.

Similarly, on Day 42, the weight of chickens fed the diets containing the probiotic BioPlus 2B was higher $(4.87 \%, P<0.01)$ compared to control chickens, whereas the weight of those fed the diets containing Avilamycin increased by $4.45 \%(P<0.05)$ compared to controls that received no growth promotor. The weight of males was $4.84 \%$ higher $(P<0.01)$ compared to females.

The weight determined during the monitoring of chickens in different phases of growth show that one-day-old chickens were ideal subjects to be administered probiotics (Mead 1989).

The effects of antibiotic and probiotic products added to the starter, grower and finisher 
Table 2. The effect of antibiotic and probiotic products on the growth of broiler chickens

\begin{tabular}{|l|c|c|c|c|c|c|}
\hline \multirow{2}{*}{ Variable } & \multirow{2}{*}{ Unit } & \multicolumn{3}{|c|}{ Products } & \multicolumn{2}{c|}{ Sex } \\
\cline { 3 - 7 } & & Control $\mathrm{a}_{0}$ & Avilamycin $\mathrm{a}_{1}$ & BioPlus 2B $\mathrm{a}_{2}$ & ${\text { Females } \mathrm{b}_{0}}{\text { Males } \mathrm{b}_{1}}$ \\
\cline { 3 - 7 } $\mathrm{n}$ & & 158 & 158 & 158 & 239 & 235 \\
\hline Weight on Day 1 & $\mathrm{g}$ & 42 & 41 & 42 & 42 & 42 \\
\hline Weight on Day 14 & $\mathrm{g}$ & $307^{\mathrm{A}}$ & $322^{\mathrm{B}}$ & $332^{\mathrm{B}}$ & 322 & 319 \\
\hline SD & $\mathrm{g}$ & \pm 42 & \pm 41 & \pm 37 & \pm 43 & \pm 39 \\
\hline Index & $\%$ & 100 & 104.89 & 108.14 & 100 & 99.07 \\
\hline Weight on Day 35 & $\mathrm{g}$ & $1516^{\mathrm{aA}}$ & $1549^{\mathrm{b}}$ & $1575^{\mathrm{B}}$ & $1494^{\mathrm{A}}$ & $1598^{\mathrm{B}}$ \\
\hline SD & $\mathrm{g}$ & \pm 178 & \pm 166 & \pm 132 & \pm 139 & \pm 165 \\
\hline Index & $\%$ & 100 & 102.18 & 103.89 & 100 & 106.96 \\
\hline Weight on Day 42 & $\mathrm{g}$ & $1931^{\mathrm{A}}$ & $2017^{\mathrm{B}}$ & $2025^{\mathrm{B}}$ & $1944^{\mathrm{A}}$ & $2038^{\mathrm{B}}$ \\
\hline SD & $\mathrm{g}$ & \pm 209 & \pm 206 & \pm 161 & \pm 178 & \pm 205 \\
\hline Index & $\%$ & 100 & 104.45 & 104.87 & 100 & 104.84 \\
\hline
\end{tabular}

Values marked with different upper case superscripts indicate a highly significant difference at $P<0.01$.

Values marked with different lower case superscripts indicate a significant difference at $P<0.05$.

Table 3. The effect of the antibiotic and probiotic product on feed consumption expressed in $\mathrm{kg}$ per $\mathrm{kg}$ of a weight gain in broiler chickens

\begin{tabular}{|c|c|c|c|c|c|c|}
\hline \multirow{2}{*}{ Variable } & \multirow{2}{*}{ Unit } & \multicolumn{3}{|c|}{ Products } & \multicolumn{2}{|c|}{ Gender } \\
\hline & & Control $\mathrm{a}_{0}$ & Avilamycin $\mathrm{a}_{1}$ & BioPlus 2B a ${ }_{2}$ & Females $\mathrm{b}_{0}$ & Males $b_{1}$ \\
\hline $\mathrm{n}$ & & 8 & 8 & 8 & 12 & 12 \\
\hline $\begin{array}{l}\text { Feed consumption, } \\
\text { Days } 1-14\end{array}$ & $\mathrm{~kg} / \mathrm{kg}$ & $1.600^{\mathrm{a}}$ & 1.528 & $1.478^{\mathrm{b}}$ & 1.530 & 1.541 \\
\hline SD & $\mathrm{kg} / \mathrm{kg}$ & \pm 0.088 & \pm 0.065 & \pm 0.067 & \pm 0.108 & \pm 0.065 \\
\hline Index & $\%$ & 100 & 95.50 & 92.38 & 100 & 100.72 \\
\hline $\begin{array}{l}\text { Feed consumption, } \\
\text { Days } 1-35\end{array}$ & $\mathrm{~kg} / \mathrm{kg}$ & $1.989^{\mathrm{a}}$ & 1.926 & $1.897^{\mathrm{b}}$ & $1.982^{\mathrm{a}}$ & $1.893^{\mathrm{b}}$ \\
\hline SD & $\mathrm{kg} / \mathrm{kg}$ & \pm 0.056 & \pm 0.109 & \pm 0.065 & \pm 0.081 & \pm 0.067 \\
\hline Index & $\%$ & 100 & 96.83 & 95.37 & 100 & 95.51 \\
\hline $\begin{array}{l}\text { Feed consumption, } \\
\text { Day } 1-42\end{array}$ & $\mathrm{~kg} / \mathrm{kg}$ & $2.199^{\mathrm{aA}}$ & $2.098^{\mathrm{b}}$ & $2.093^{\mathrm{B}}$ & 2.163 & 2.097 \\
\hline SD & $\mathrm{kg} / \mathrm{kg}$ & \pm 0.036 & \pm 0.088 & \pm 0.069 & \pm 0.059 & \pm 0.090 \\
\hline Index & $\%$ & 100 & 95.40 & 95.18 & 100 & 96.95 \\
\hline
\end{tabular}

Values marked with different upper case suprescripts indicate a highly significant difference at $P<0.01$.

Values marked with different lower case superscripts indicate a significant difference at $P<0.05$.

diets on feed consumption (expressed in $\mathrm{kg}$ per $\mathrm{kg}$ of weight gain) are illustrated in Table 3. Consumption of the starter in the period from Day 1 to Day 14 was $7.62 \%$ lower in Group $\left(\mathrm{a}_{2}\right)(P<0.05)$ compared to Group $\left(\mathrm{a}_{0}\right)$. A $4.5 \%$ difference found between Groups $\left(a_{1}\right)$ and $\left(a_{0}\right)$ was non-significant. Similarly, feed consumption (expressed in kg per $1 \mathrm{~kg}$ of weight gain) in male and female chickens did not differ significantly in this period. Feed consumption (starter and grower) in the group of chickens with the probiotic in the period from Day 1 to Day 35 showed a $4.63 \%$ decrease $(P<0.05)$ compared to the control. Feed consumption in the group with Avilamycin decreased by $3.17 \%$, which was just on the threshold of significance. The consumption of diets in male chickens was $4.49 \%$ lower $(P<0.05)$ compared to females.

The consumption of diets (starter, grower and finisher) in a period of broiler fattening, i.e. from Day 1 to Day 42 , decreased $(4.82 \%, P<0.01)$ in chickens fed the probiotic 
BioPlus 2B compared to control chickens. Feed consumption in males for the whole period was $3.05 \%$ lower compared to females.

Similar findings were reported by Fritts et al. (2000) who used the probiotic containing Bacillus subtilis C-3102 (Calsporin) as an additive supplied to diets for broiler chickens, achieving improved performance and better stabilization of microflora in the digestive tract, as clearly confirmed by the above-mentioned results.

The mean values of slaughter yield (Table 4$)$ were $(P<0.01)$ higher in chickens fed the diets containing the probiotic $\left(a_{2}\right)$, and antibiotic $\left(a_{1}\right)$ compared to controls $\left(a_{0}\right)$ for which the diets were not supplemented with any growth promotor. The amounts of inner fat in monitored chickens varied markedly and failed to show any significant difference between experimental groups and sexes.

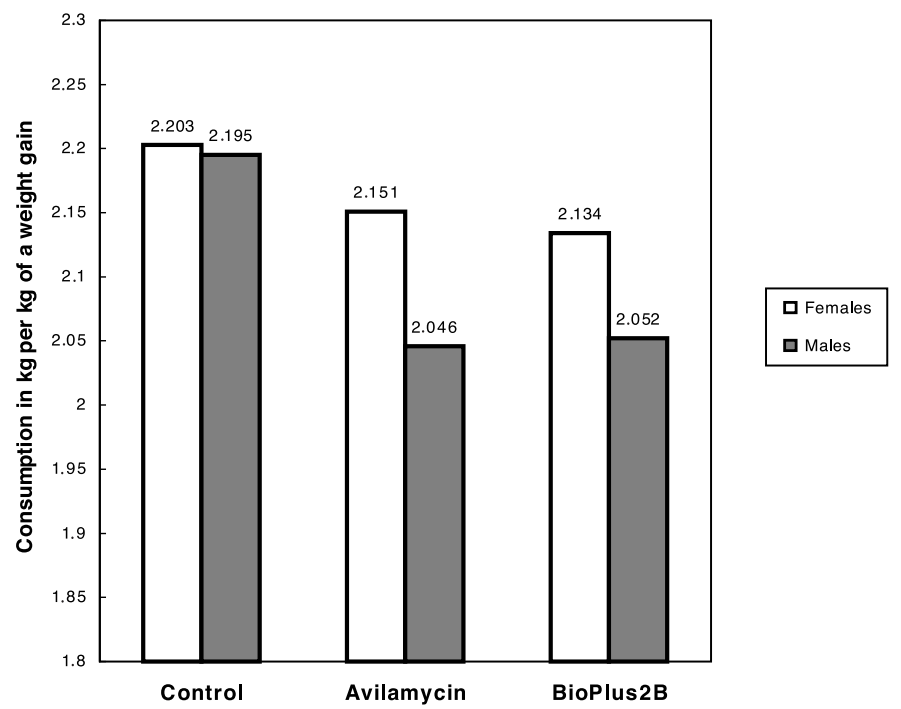

Fig. 1.The effect of the antibiotic and probiotic product on feed consumption expressed in $\mathrm{kg}$ per $\mathrm{kg}$ of a weight gain in broiler chickens, Day 1-42.

The health status and mortality rates were followed throughout the experiment. Necropsy revealed that the causes of death were not related to the products used.

Our results show that the probiotic BioPlus $2 \mathrm{~B}$ containing exactly specified strains of Bacillus subtilis - CH 201 and Bacillus licheniformis - CH 200 as active components has a beneficial effect on both animal growth and nutrient conversion. In conclusion, BioPlus $2 \mathrm{~B}$ can be used as an alternative growth promotor to be added to the diets designed for broiler fattening.

\section{Probiotický preparát BioPlus 2B, alternativa antibiotik v krmných směsích pro kuřecí brojlery}

Cílem této práce bylo srovnat stimulační efekt probiotického preparátu BioPlus 2B $\mathrm{s}$ antibiotikem Avilamycin na růst a konverzi krmiv u brojlerových kuřat. Byl uspořádán růstový pokus s jednodenními kurričkami a kohoutky hybrida ROSS 308. Celkem bylo v pokusu umístěno 240 kuřiček a 240 kohoutků ve 24 klecích.Od 1. do 14. dne věku přijímala kuřata směsi BR1, od 15. do 35. dne věku směsi BR2 a od 36. do 42. dne věku pak směsi BR3 v sypké formě. Kuřata přijímala krmné směsi a vodu ad libitum. Na konci pokusu ve 42. dnu byly provedeny kontrolní porážky kuřat ke stanovení podílu konzumní 
části kuřat a podílu vnitřního tuku ve finálním výrobku. Zařazením preparátu BioPlus $2 \mathrm{~B}$ do krmných směsí pro předvýkrm a výkrm brojlerů lze dosáhnout o 4-5 \% vyšší hmotnosti kuřat a o 4-5 \% zlepšit konverzi přijatého krmiva a tím snížit spotřebu směsí na $1 \mathrm{~kg}$ př́růstku. Průměrné hodnoty jateční výtěžnosti byly významně $(P<0,01)$ vyšší u kuřat krmených směsmi jak s probiotickým tak i antibiotickým preparátem oproti skupině kuřat, jimž do krmných směsí nebyl aplikován žádný růstový stimulátor. Hmotnost vnitřního tuku u sledovaných kuřat nevykazovala významný rozdíl jak mezi pokusnými skupinami, tak i pohlavím.

\section{Acknowledgement}

Supported by the Ministry of Education, Youth and Sports of the Czech Republic (Grant No MSM $6215712402)$

\section{References}

EFSA 2003: Opinion of the scientific panel on additives and products or substances used in animal feed on microorganism product BioPlus 2B, authorised as feed additive in accordance with Council Directive 70/524/EEC, EFSA-Q-2003-008, www.efsa.europa.eu.

FRITTS CA, KERSEY JH, MOTL MA, KROGER EC, YAN F, SI J, JIANG Q, CAMPOS MM, WALDROUP AL, WALDROUP PW 2000: Bacillus subtilis C-3102 (Calsporin) improves live performance and microbiological status of broiler chickens. J Appl Poult Res 9: 149-155

GHADBAN GS 2002: Probiotics in broiler production - a review. Arch Geflugelkd 66: 49-58

KUMPRECHT I, ZOBAČ P 1998: The effect of Bacillus sp. based probiotic preparations in diets with different protein contents on performance and nitrogen metabolism in chick broilers. Czech J Anim Sci 43: 327-335

KUMPRECHT I, ZOBAČ P 2000: Probiotic and enzyme preparations - alternatives to antibiotic and chemical additives to diets for monogastric animals. Vet Med - Czech 45: 110

MEAD GC 1989: Microbes of the avian cecum: types present and substrates utilized. J Exp Zool Suppl 3: 48-54

O'DEA EE, FASENKO GM, ALLISON GE, KORVER DR, TANNOCK GW, GUAN LL 2006: Investigating the effects of commercial probiotics on broiler chick quality and production efficiency. Poult Sci 85: 1855-1863

PATTERSON JA, BURKHOLDER KM 2003: Application of prebiotics and probiotics in poultry production. Poult Sci 82: 627-631

SNEDECOR GW, COCHRAN WC 1967: Statistical methods. $6^{\text {th }}$ ed. Ames, Iowa State University Press, $130 \mathrm{p}$. 